\title{
Hydrogeomorphological Mapping Upto Cadastral Level, By Using High Resolution Satellite Data In Gokaphaslwada Watershed, Doulthabad Mandal, Mahabubnagar District
}

\author{
Narsimha Kota ${ }^{1, *}$, Nallaganthula Ramudu ${ }^{2}$, S. Ravikumar ${ }^{3}$, M.Suresh ${ }^{4}$ \\ Research Associate, Rural Development Society, Prestige Rai Towers, Flat No.404, B-Block, Punjagutta, \\ Hyderabad, Telangana, and India ${ }^{1,2,3}$.
}

\begin{abstract}
Mahabunagar District falls in rain shadow zone with a low annual normal rainfall of $604 \mathrm{~mm}$. The recurrence of drought is increasing considerably and unless collective measures are initiated on a permanent basis the situation will become grim in future. Gokaphasalwada watershed in Mahabubnagar District is selected to demonstrate the capability of high resolution satellite data in ground water mapping at village level. This watershed is located in Survey of India toposheet Nos. 56H/9 NW. This watershed with an area of about 57 sq. $\mathrm{km}$ is underlined by granite gneiss and migmatite traversed by dolerite dykes. Hydrogeomorphological mapping was carried out on 1:10,000 scale using IRS-P6 LISS-IV satellite data. The satellite data facilitates to update the extent of built-up area, road and drainage network. Further, the revenue villages enclosed in the watershed are digitized, geo-referenced, mosaicked and superimposed on hydrogeomorphology map. This helps to give site specific recommendation and proposing survey number wise water harvesting structures which will improve the ground water resources.
\end{abstract}

\section{Introduction}

The study area "Gokaphaslwada watershed" falls in southern side of part of Doulathabad mandal of Mahabubnagar District, Telangana State, India. The extent of watershed stretches in between $77^{\circ} 36^{\prime}$ '54" and $77^{\circ} 32^{\prime} 11^{\prime \prime}$ East Longitudes and $16^{\circ} 59^{\prime} 25^{\prime \prime}$ and $16^{\circ} 55^{\prime} 49^{\prime \prime}$ North Latitudes and is covered by the Survey of India Toposheet number $56 \mathrm{H} / 9 \mathrm{NW}$ with an area of 5,775 hectares (57 Sq Kilometers).

About $90 \%$ people in the study area are dependent on agriculture and allied sectors. The present study is taken on the development of Groundwater Resources Development in Watershed level. The database pertaining to different thematic layers like landuse / landcover, soil map hydrogeomorphology, lineament map etc are prepared as part of the project by Remote sensing techniques and Arc-GIS software. An action plan map of the Gokaphaslwada watershed, by using different thematic information, the Groundwater resources Evaluation information and conservation measures and predictions and which will be used in management of watershed, and in solving the drought problems.

\section{Objective}

Preparation of Hydrogeomorphology map on 1:10,000 scale by using high resolution (IRS-P6 LISS IV) satellite data and GIS techniques and proposing water harvesting structures on watershed management principles.

\section{Location and Extent}

Doulthabad watershed is located in Doulthabad Mandal and occupying an area of $57 \mathrm{Sq} \mathrm{km}$, covered by villages like Gokaphasalwad, Timmareddipalli, polkampalli, Banglathanda, timmapur, sulthapur in Doulthabad and Damaragidda Mandal mahabubnagar District.The maximum 601 and 560 minimum elevations of the study area. The Location Map and IRS P-6 LISS-IV Satellite imagery is as shown in Fig. 1 \& 2 respectively. 


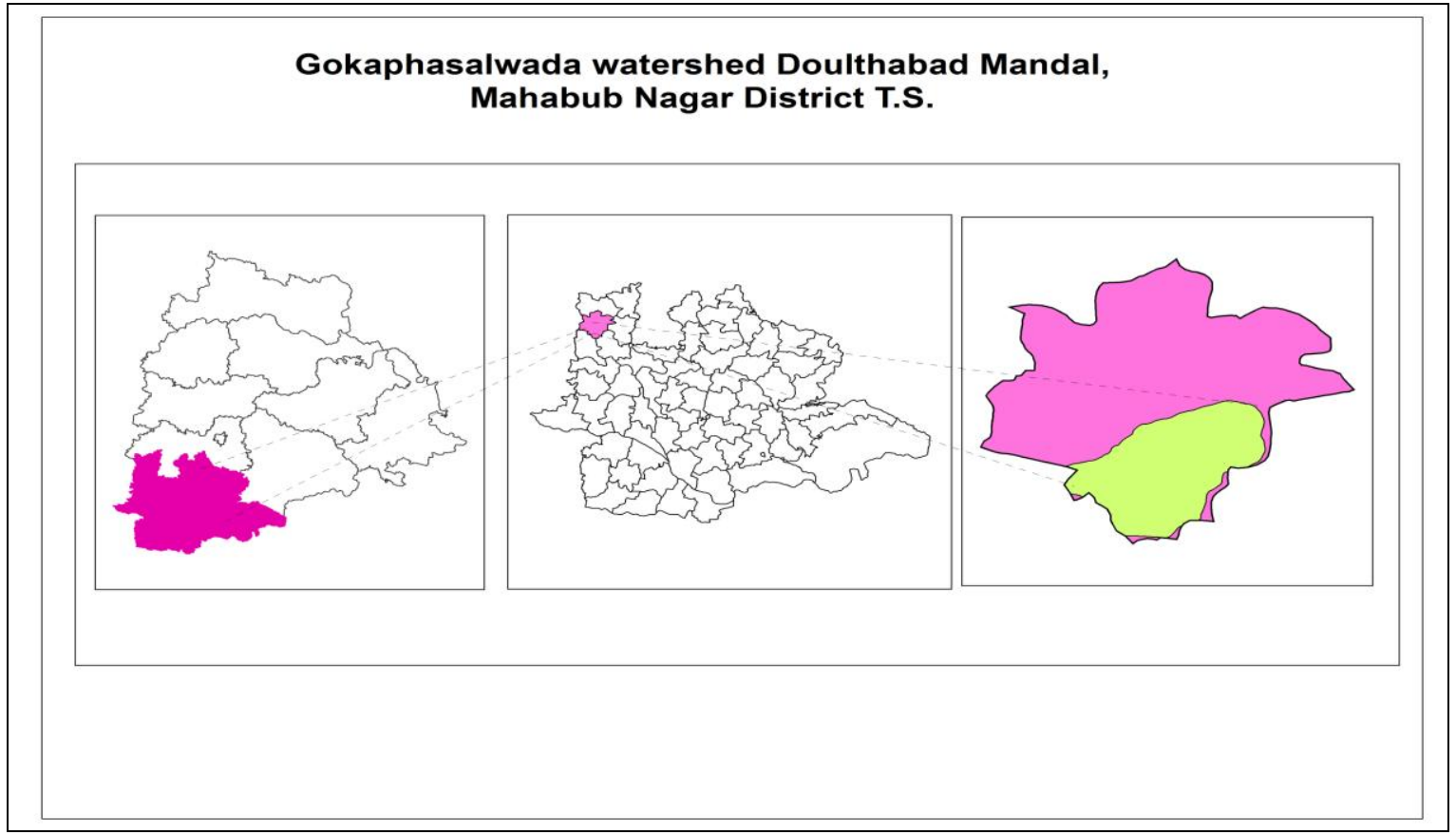

Fig. 1 Location map showing Gokaphasalwada watershed

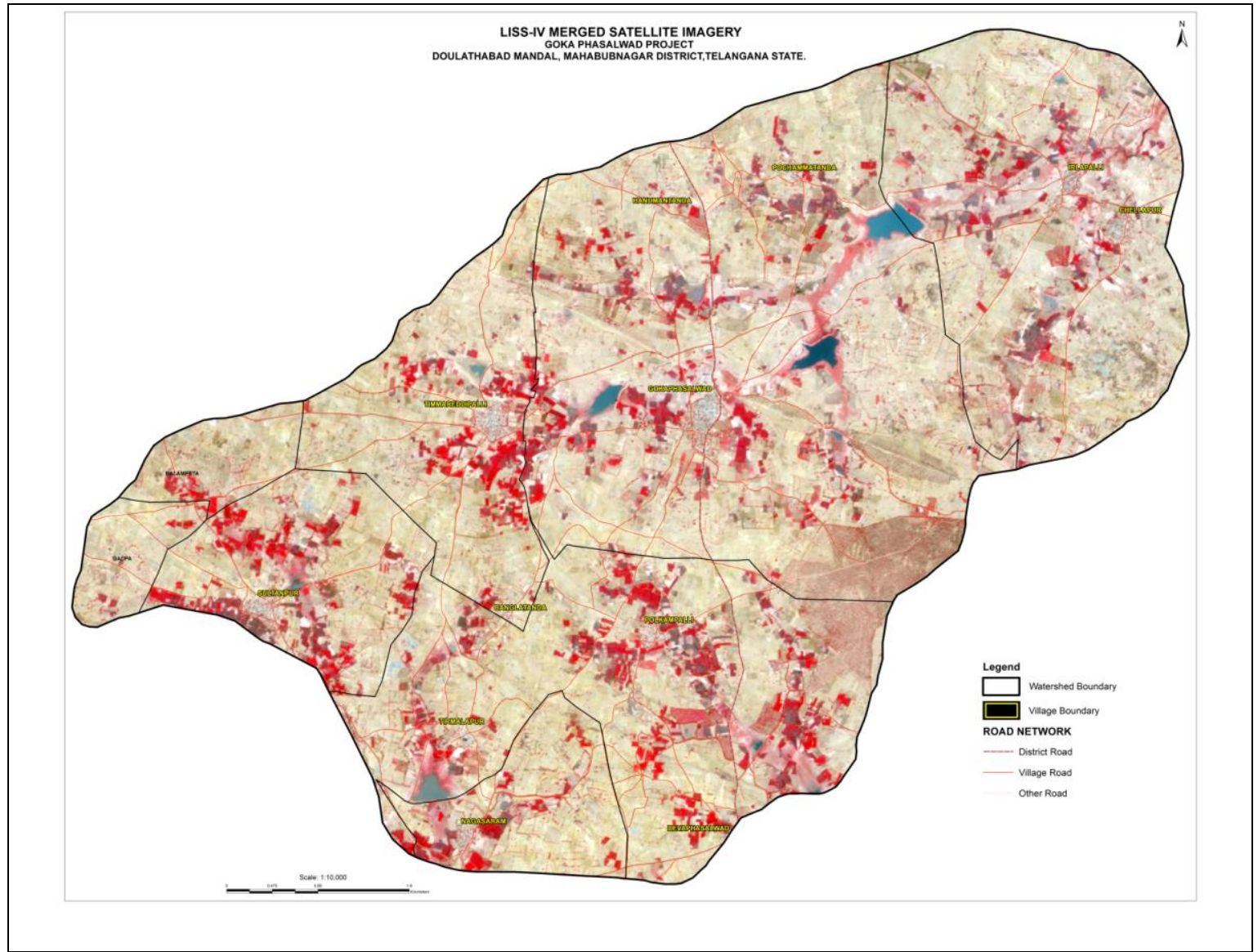

Fig. 2 Satellite image of Gokaphaslwada watershed 


\section{Methodology}

High resolution Indian Remote Sensing satellite, IRS-P6 LISS-IV data of $3^{\text {rd }}$ March 2012 with a spatial resolution of $5.8 \mathrm{~m}$ covering parts of Doulthabad and Damaragidda Mandals is analyzed. Onscreen interpretation is carried out and delineated different geomorphological units / landforms, lithological formations, geological structures and hydrogeomorphological map by using other ancillary data are prepared. By using the $5.8 \mathrm{~m}$ resolution satellite data, we will get more accurate site specific details i.e. up to cadastral level.

\subsection{Thematic Layers}

The following different thematic layers were prepared as part of the project.

4.1.1 DRAINAGE MAP: Drainage map of the study area has been prepared from the SOI Toposheet and updated using high resolution satellite of IRS P-6 LISS IV. The watershed area shape is elongated and consisting of dendritic drainage pattern, with the stream order ranging from $1^{\text {st }}$ to $3^{\text {rd }}$ order. The drainage map is as shown in Fig. 3

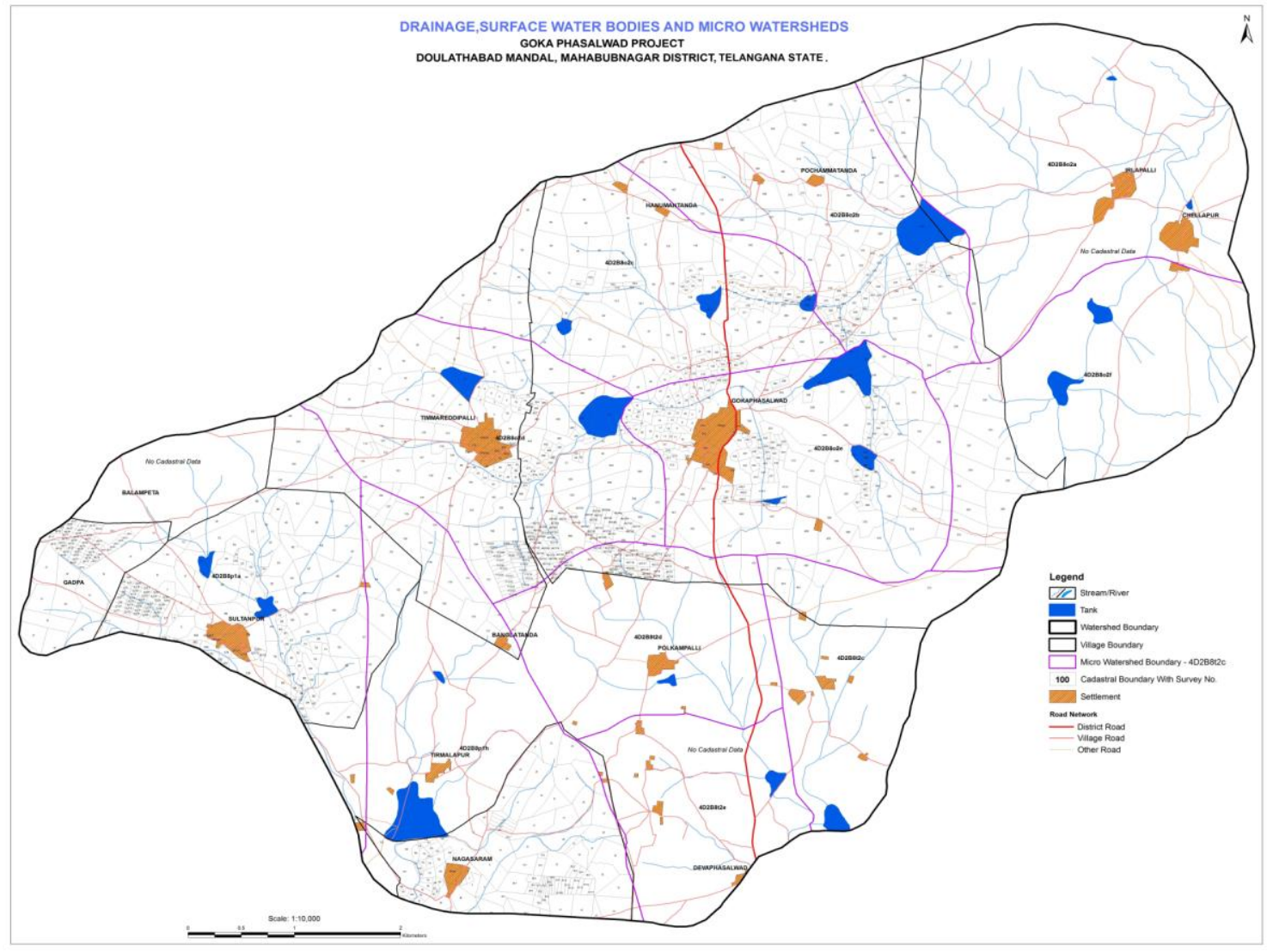

Fig. 3 Drainage map of Gokaphasalwada watershed

\subsubsection{Geology\& Structure}

Gokaphasalwada Watershed is underlain by the formation of peninsular graniessic complex (Granite gneiss Migmatite) of Achaean age. Geologically Gokaphasalwada watershed is stable and consisting of hard rock terrain of granite, gneiss and migmatite. The area is marked by numerous fractures and the drainage is mainly controlled by these fractures / lineaments.

A number of lineaments running in NE-SW directions are identified. Major lineaments are noticed in the area of Doulthabad.

\subsubsection{Hydrogeomorphology:}

The hydrogeomorphology units obtained are moderately weathered pediplain, Shallow weathered pediplain, Pediment, pediment inselberg complex, tor, and dyke.

Moderately Weathered Pediplain (PPM): It is a gently sloping smooth surface of granite gneiss with more than $10 \mathrm{~m}$ depth of weathered material, generally covered with red soil. In general, the ground water prospects are moderate to good. Good to Very Good yields can be expected along fractures / lineaments. Ground water 
development is extensive in these areas due to the availability of good ground water potential. These landforms are developed throughout catchment area.

Shallow Weathered Pediplain (PPS): It is a gently sloping smooth surface of Granite gneiss with less than 10 $\mathrm{m}$ depth of weathered material, generally covered with red soil. The ground water prospects are poor to moderate. Moderate to Good yields are expected along fractures / lineaments.

Dyke: Moderately sloping, shallow, reddish brown gravelly sandy loam, severely eroded, well drained and neutral in soil reaction.

Pediment (PD): It is a gently sloping rock-cut surface of granite with thin veneer of detritus. In general, the ground water prospects in a pediment area are poor. These rock-cut outcrops are exposed extensively near hill area.

Pediment-Isenberg Complex: The pediments dotted by numerous inselberg of small sizes, which makes it difficult to distinguish from the pediments. Hence it is called as a complex of pediment and inselberg.

Tor: A high, isolated, craggy hill, pinnacle, or rocky peak or a pile of rocks, much-jointed and usually granitic, exposed to considerable weathering, and often assuming peculiar or fantastic shapes.

\begin{tabular}{|c|c|c|c|c|}
\hline \multirow{8}{*}{ Area in ha } & \multirow{2}{*}{ - Dyke ridge } & Land form & Area in Sq km & Area in ha \\
\hline & & Dyke ridge & 0 & 63 \\
\hline & \multirow{2}{*}{ " Pediment } & Pediment & 22 & 2269 \\
\hline & & Pediment inselberg & 1 & 67 \\
\hline & \multirow{4}{*}{$\begin{array}{l}\text { - Pediplain moderately } \\
\text { westherd } \\
\text { Pediplain shallow } \\
\text { weollieru } \\
\text { "Tor }\end{array}$} & Pediplain moderately weatherd & 10 & 1008 \\
\hline & & Pediplain shallow weatherd & 24 & 2345 \\
\hline & & Tor & 0 & 24 \\
\hline & & Grand Total & 57 & 5776 \\
\hline
\end{tabular}

\subsubsection{Ground Water Prospects:}

Study of geological, hydrological, and meteorological data provides information on the parameters such as rock types, geological structures, landforms, and recharge conditions which control the occurrence and distribution of ground water. Remote Sensing based study has been carried out for hydrogeomorphological mapping to identify various landforms based on their groundwater prospects for tapping groundwater. Groundwater potential zones were delineated from hydro geomorphology, and structural information. The study area is divided into various Hydro geomorphic units based on landforms, genesis, geology, soils etc.

The major landforms of the area include shallow weathered pediplain, moderately weathered pediplain, Pediment inselberg complex, pediment, and Dykes. The ground water prospects in shallow weathered pediplain are moderate to poor and while in pediplain moderately Weathered the prospects are good to moderate. In pediments, the ground water Prospects are negligible to poor while in hilly areas it is negligible. Excellent groundwater prospects may be expected in the fracture valley depending upon the thickness for the weathered material.

In the Study area, the groundwater occurs under water table conditions in the weathered rock and in fractured rock it is under semi-confined to confined conditions. The study area is predominantly underlined by hard rock's which have very low permeability or transmissivity values. But, due to the development of secondary porosity with the introduction of fracturing and weathering, they have improved chances of tapping potential aquifers. The dykes which are acting as barriers to ground water movement also has improved yield prospects along one side of the dykes.

The degree of weathering in the hard rock's varies from a meter to as much as more than $15 \mathrm{~m}$. The degree of fracturing and depth of fracturing varies from place to place. In general, as evidenced by CGWB exploratory drilling in the district, the intensity and occurrence of fracturing reduce after $80 \mathrm{ft}$ depth and mostly after110 ft depth.

Major part of the study area consists of pediments and dykes with poor to negligible ground water prospects. In middle of the watershed there exists pediplain shallow weathered with moderate to poor groundwater conditions. Different water conservation structures like check dams, percolation tanks, recharge pits, desilting of tanks etc are proposed at cadastral level by using hydrogeomorphological map. The predominant groundwater irrigated areas along lineament, and facture systems brought out by satellite data interpretation are of immense use for taking up artificial recharge structures. The locations which are recommended for artificial recharge structures (check dams / percolation tanks) are upstream of the irrigated areas for sustenance of bore wells in downstream and which will improve the water availability through recharging the ground water by surface spreading. 


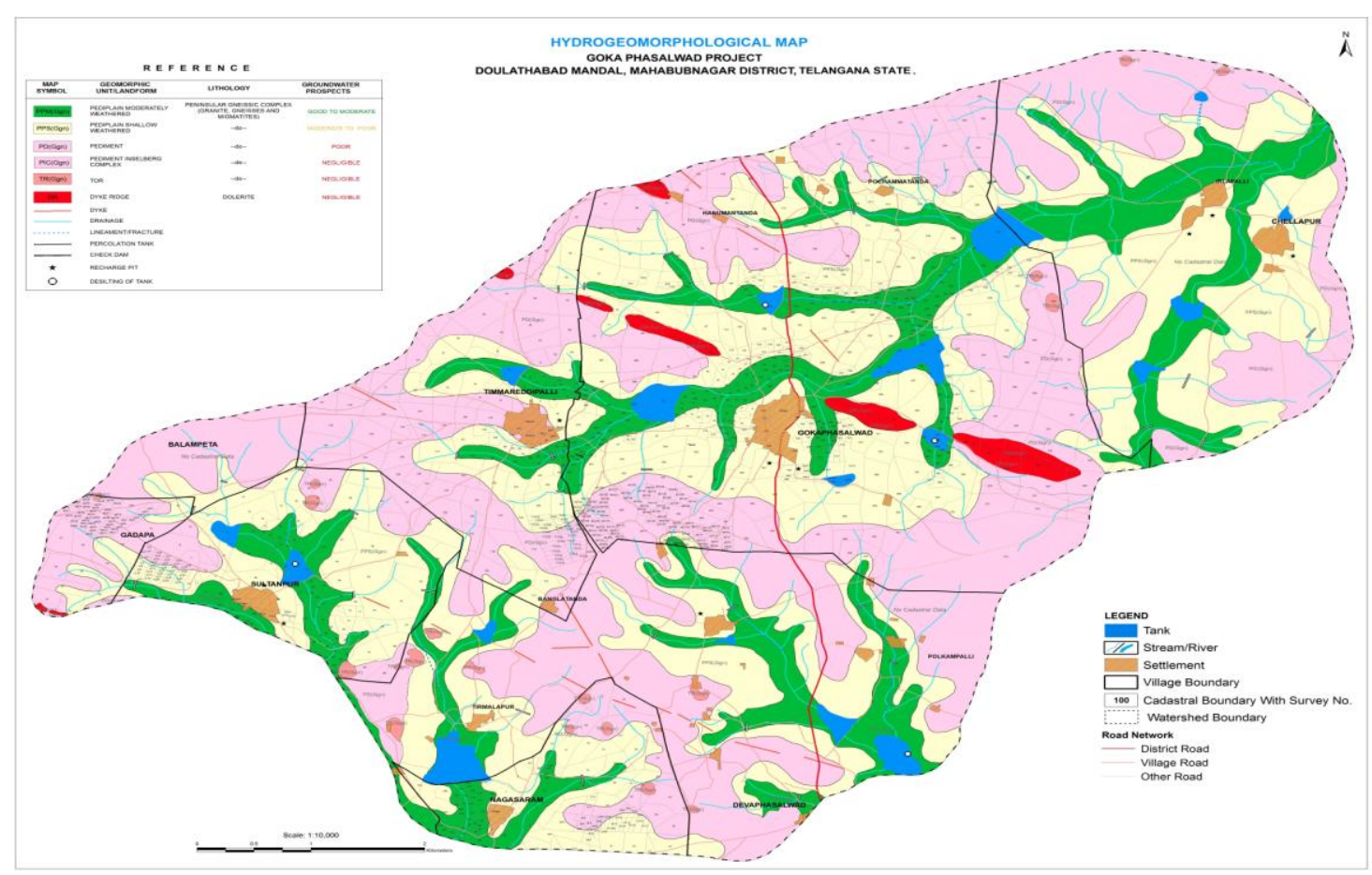

Fig .4 Hydrogeomorphological map of Gokaphaslwada watershed.

\section{Conclusions}

The Indian Remote Sensing satellite (IRS P6 LISS-IV) data with a spatial resolution of $5.8 \mathrm{~m}$ can be extended for getting information up to 1:4,000 scale. With the help of high resolution data, expansion of rural settlements, drainage and road network is updated. The boundaries of all geomorphic units are drawn more precisely. With the advent of high resolution satellite data, site-specific recommendations for ground water exploration can be given at cadastral level for effective management of ground water resources at smallest possible revenue boundary i.e. in the individual fields of the farmers. The effect of check dams resulted in stabilizing the water levels in the wells, increasing the pumping hours, rejuvenating the abandoned wells. The ground water level will be increased and this promises to bring the benefits of green revolution hitherto untouched by adopting a farming system approach in order to conserve precious rain water and equally conserving soil resource as well.

\section{Recommendations}

Water Conservation: A good understanding of water conservation with reference to their nature and distribution is essential to formulate any land based production system. The watershed as a planning unit for development of land and water resources has gained importance since the Ministry of Agriculture, Government of India, initiated various developmental programmers on watershed basis. According to the guide lines given by the department of Agriculture, the soil and water conservation measures have been recommended for the 'Gokaphaslwada' watershed depending upon the land attributes. Check dams are proposed on lower order streams to control water velocity and to store the water.

Check Dam: Proposed on the $2^{\text {rd }}$ order streams along the foot hill zones and in the areas with 0-5\% slope.

Desilting of Tanks: The Desilting of tanks is recommended in small tanks which are partially silted up. Siltation in the tanks is found by study of the image and ground truth.

Ground Water Development with Conservation Measures: To increase crop lands, horticulture and nurseries, groundwater exploration is suggested which is not earlier exploited in moderate range. Horticulture plantations with interspaced cultivation can bring better returns than the field crops. Interspaces in horticulture plantations may be grown with vegetables in both seasons. Different tree species are recommended for forest nurseries.

Fodder / Fuel Wood Plantation: These are suggested in the marginal lands with poor groundwater potential areas and not able to sustain crops. The open forest areas may be converted into grazing lands by over seeding grasses and fuel wood species are recommended to meet the demand of local people requirement.

Afforestation: Afforestation is proposed in the forest blanks / open forest areas to increase the density of vegetation. These gaps may have been caused due to several reasons which include grazing in the initial stage 
and unauthorized tree felling. The economic forest plantations are suggested for compensating forest degradation.

Wastelands: Land with or without scrub (Scrub Lands) come under this category. Over seeding on grasses, silvipasture, and agro-forestry plantation are recommended on upland with or without scrub. Water harvesting structures like loose boulder check dams / Rock dams using available local stones in middle slopes that will help in raising soil moisture; in slopes at higher reaches brushwood dams and rubble dams will arrest soil erosion.

\section{References}

[1]. Bhagavan, S.V.B.K and Raghu, V. (2000). "Integrated Remote Sensing based Study of National Watershed Development Project for Rained Area in A.P”. Abstract Volume of National Symposium on Remote Sensing for Natural Resources with Special Emphasis on Watershed Management, Bhubaneswar, and pp.15.

[2]. Central Research Institute for Dry land Agriculture, (1990). Field Manual on Watershed management, CRIDA, Hyderabad

[3]. Department of Space/ ISRO (1988). Manual for Hydrogeomorphological mapping for drinking water mission.

[4]. NRSA (National Remote Sensing Agency) 2008. Ground Water Prospects Mapping Using Remote Sensing and Geographic Information System, Rajiv Gandhi National Drinking Water Mission Project, Manual,256p.

[5]. 18. Sankar, K. (2002), Evaluation of Ground water potential zones using Remote Sensing Data in Upper Vaigai River basin, Tamilnadu, India. J. Indian Soc. Remote Sensing, 30(3), pp 119-128.

[6]. 19. Sparks, B.W. (1960), Landform in arid and semi-arid climates; Geomorphology 2nd edition, (Longman Group Ltd.), pp 335341 .

[7]. 20. Subba Rao N., Chakradhar. G.K.J. and Srinivas V, (2001), Identification of Groundwater Potential Zones using Remote Sensing techniques In and Around Guntur town, Andhra Pradesh, India, Journal of the Indian Society of remote Sensing, 29(12), pp 69-78.

[8]. Sabins, F. F., (1997), Remote Sensing Principles and Interpretation, W. H. Freeman \& Company. Newyork. 